\title{
Proline Activity and Growth of Oil Palm affected by Aluminium Toxicity and Silica as Ameliorant
}

\author{
Annisa Khoiriyah*, Eka Tarwaca Susila Putra, Prapto Yudono \\ Department of Agronomy, Faculty of Agriculture, Universitas Gadjah Mada \\ Jln. Flora no. 1, Bulaksumur, Sleman, Yogyakarta 55281 \\ *Corresponding email: niisaakhoir@gmail.com
}

Received: $4^{\text {th }}$ May 2016; Revised: 24 ${ }^{\text {th }}$ June 2016; Accepted: 23' January 2017

\begin{abstract}
The research aims to investigate the effects of silica ( $\mathrm{Si}$ ) as an ameliorant on the proline compound concentration and the growth response of oil palm exposed to aluminum toxicity. The research was arranged in a complete randomized block design with 8 blocks as replications. The first factor was Al toxicity which consisted of two levels as without and with $\mathrm{Al}$ toxicity. Al toxicity treatment was applied by giving $300 \mathrm{ppm}$ of Al concentrate along with watering activity regularly. The second factor was the application of silica which consisted of four levels as $0,32,64 \mathrm{~g} / \mathrm{plant}$. Proline and growth activities of leaf area, plant height, number of leaves, and dry weight were observed in the research. The data subjected to analysis of variance (ANOVA) at 5\% test level. If the result of ANOVA showed significant differences among treatments, then the data would have been analyzed by Duncan's Multiple Range Test (DMRT) at 5\% test level. The results of the research provide information that Al toxicity increases proline compound in the plant tissues and decreases leaf area, plant height, number of leaves, and dry weight of Oil Palm. Applying Si at the level of 64 $\mathrm{g} / \mathrm{plant}$ could increase proline concentrate and dry weight of oil palm exposed to A1 toxicity. Proline compound in the plant tissues did not have any correlation with the growth of oil palm. Thus, this case indicated that proline was a product and not a plant tolerant mechanism of Al toxicity.
\end{abstract}

Keywords: Aluminum, Growth, Proline, Silica, Stress

\section{INTRODUCTION}

Aluminium ( $\mathrm{Al})$ is a rhizotoxic ion which inhibits plant growth and plant's productivity in acid soil (Huang and Violante, 1997). Al toxicity occurs when there is an accumulation in root tissue that inhibits the cell divisions and elongation as well as the activity of enzyme in synthesizing many compounds in cell walls (Rorison, 1973). According to Clarkson (1969), Al inhibits hexokinase activities such as phosphatase and ATP-ase and it inhibits the phosphorylation. Forforilase barriers cause ATP to form, yet hexaphospate such as glucose-6phosphate and ADP formation would be disrupted. According to Enggarini and Marwani (2006), phosphorylation disruption leads to leaf chlorosis, nutrient deficiency, and stunt.

Oil palm has many benefits as it is used for food products, pharmaceuticals, and cosmetics.
According to IMA (2010), since 2007, Indonesia has become the largest oil palm manufacturer which grows rapidly. Its production has increased from 168,000 tons in 1967 to 22 million tons in 2010. The increased prices of crude palm oil (CPO) and palm kernel oil (PKO) have prompted the investors to expand the plantations on large and areas in Sumatra and Kalimantan.

Oil palm mostly is cultivated in high rainfall areas 2000 to $3000 \mathrm{~mm}$ per year (Risza, 2008). This condition causes Al stress which possibly it occurs at high intensity in the oil palm cultivation. The expansion of planting area now is also very difficult due to limited suitable area for oil palm commodity and province spatial planning policies. Meanwhile, the usage of marginal area for particularly wet marginal area could be a solution to solve this problem. The factor of limitation of oil palm cultivation on wet marginal area is its poor soil and infertility caused by high acidic cations 
including Al.

Oil palm which is cultivated on highly Alcontented soil suffers Al stress and is suspected to have drought stress. Al, which is accumulated in the cell in soybean (Rengel, 1997), can disrupt membrane permeability and interfere nutrient absorption that is regulated by proton pump. Inhibition of nutrient and water absorption from the soil triggers imperfect root growth in which the root system becomes shallow and more sensitive to drought stress. Proline is a biochemical compound that is mostly synthesized and accumulated in various plant tissues, mainly in the leaves under drough stress. Proline acts as a free radical scavenger (Ashraf and Foolad, 2007) and osmoprotectant compound for cell osmotic adjustment (Hamim et. al., 2008). Plants exposed to Al-stress are assumed to have less optimal growth since it is caused by disruption of nutrient and water absorption. According to Hanum et. al. (2009), soybean suffering Al toxicity and drought stress has less dry weight. In the case of sorghum (Galvez and Clark, 1991), the higher Al absorbed by the plant causes lower dry weight.

Silica is assumed to be possibly used to reduce $\mathrm{Al}$ toxicity in plants. The mechanism is through a reduction of $\mathrm{Al}^{3+}$ activity in the soil solvent, and it reduces Al toxicity on the plant body (Savant et. al., 1999). Silica application can improve the efficiency of photosynthesis, so it enhaces sufficient assimilations for the growth and development of plants (Matichenko and Calvert, 2002). Related with proline activities, according to the study of Shahnaz et. al. (2011), silica can increase the production of proline in plants which are exposed to Al-stress. The information about growth response and proline activity of oil palm exposed to Al-stress and added with silica application is not available yet. Thus, this study is quite important to do.

\section{MATERIALS AND METHODS}

This research was conducted in Bendosari, Madurejo, Prambanan, Sleman, Crop Science Laboratory, Faculty of Agriculture, Universitas Gadjah Mada from June 2014 to June 2015. Planting materials used were hybrid oil palm seeds originated from Oil Palm Research Center, Medan. This research was arranged in completely randomized block design with $2 \times 4$ factorials with eight blocks as replications. The first factor was Al-stress consisting of two levels that are without and with $\mathrm{Al}$ toxicity. $\mathrm{Al}$ toxicity was generated from aluminum sulfate $\left(\mathrm{Al}_{2}\left(\mathrm{SO}_{4}\right)_{3}\right)$ at 300 $\mathrm{ppm}$ concentration. The second factor was the dosage of silica which consisted of four levels, 0,32 , 64 and $96 \mathrm{~g} /$ plant.

The variables observations included leaf area, plant height, number of leaves, and dry weight. Plant height was measured using a ruler starting from the base of the stem above the ground to the tip of the highest leaf. Leaf area was measured using leaf area meter while the dry weight was measured using oven at $65^{\circ} \mathrm{C}$ to $75^{\circ} \mathrm{C}$ for 48 hours. The growth observation was done twice during 4 weeks after $\mathrm{Al}$ treatment and when the plant was showing the symptoms of stress.

Proline content was determined by spectrophotometry method according to Bates (1973); Umebese (2009). Frozen leaf tissue $(0,5 \mathrm{~g})$ was homogenized with 10 $\mathrm{mL}$ of $3 \%$ sulfosalicylic acid at $4{ }^{\circ} \mathrm{C}$. The extract was filtered with Whatman no. 2 filter paper. In a test tube, $2 \mathrm{~mL}$ of filtrate, $2 \mathrm{~mL}$ of acid-ninhydrin, and 2 $\mathrm{mL}$ of glacial acetic acid were mixed and incubated at $100{ }^{\circ} \mathrm{C}$ for $1 \mathrm{~h}$. The reaction was terminated on ice, and the reaction mixture was then extracted with $4 \mathrm{ml}$ of toluene. The chromophore-containing toluene was separated from the hydrated phase. The absorbance at $520 \mathrm{~nm}$ was spectrophotometrically determined with toluene as the blank (Çelik and Atak, 2012). The proline concentration was calculated based on a standard curve and was expressed as $\mu$ mol proline $\mathrm{g}^{-1} \mathrm{FW}$.

The data obtained were analyzed with ANOVA Data for variables showing significant difference among treatments then were analyzed using Duncan's Multiple Range Test (DMRT) with 5\% test level. Analysis was conducted by $\mathrm{SAS} \circledast$.

\section{RESULT AND DISCUSSION}

$\mathrm{Al}$ accumulated in the cell could disrupt membrane permeability and nutrient absorption. Subsequently, proline accumulated in a large amount as an osmoprotectant compound was a respond toAl toxicity. There is an interaction between $\mathrm{Al}$ toxicity and Si dosage (Table 1). The content of proline increased along with $\mathrm{Al}$ toxicity and application of $\mathrm{Si}$ as an amelioration. The dosage of $64 \mathrm{~g} /$ plant of $\mathrm{Si}$ was able to stimulate the synthesis of proline in oil palm in which Al toxicity had been induced, though it was not significantly different from the $32 \mathrm{~g} /$ plant dosage of Si. This result was in accordance with the study of Shahnaz et. al. (2011), mentioning that application of Si increases proline synthesis in Borago officinalis L. Jain et. al. (2001) state that proline is considered as a source of carbon and nitrogen for quick recovery of plants from the stress. 
Table 1. The proline content in leaf tissues of oil palm (ppm)

\begin{tabular}{|c|c|c|c|c|c|}
\hline \multirow{2}{*}{ Treatments } & \multicolumn{4}{|c|}{ Si Dosage (g/plant) } & \multirow{2}{*}{ Mean } \\
\hline & $\mathbf{0}$ & 32 & 64 & 96 & \\
\hline Without Al & $26.97 \mathrm{~d}$ & $31.19 \mathrm{~d}$ & $22.52 \mathrm{~d}$ & $20.13 d$ & 25.20 \\
\hline Al Toxicity & $66.55 \mathrm{c}$ & $120.51 \mathrm{ab}$ & $153.34 \mathrm{a}$ & $107.91 \mathrm{~b}$ & 112.08 \\
\hline Mean & 46.76 & 75.85 & 87.93 & 64.02 & $(+)$ \\
\hline $\mathrm{CV}$ & & & 11.59 & & \\
\hline
\end{tabular}

Table 2. Leaf area of oil palm on the first and second observation $\left(\mathrm{cm}^{2}\right)$

\begin{tabular}{|c|c|c|c|c|c|c|}
\hline \multirow{2}{*}{ Obs } & \multirow{2}{*}{ Treatments } & \multicolumn{4}{|c|}{ Si Dosage (g/plant) } & \multirow{2}{*}{ Mean } \\
\hline & & $\mathbf{0}$ & 32 & 64 & 96 & \\
\hline \multirow{4}{*}{1} & Without Al & 3330.92 & 2821.03 & 2905.26 & 2475.63 & $2883.21 \mathrm{p}$ \\
\hline & Al Toxicity & 1780.38 & 2156.98 & 2330.53 & 2265.05 & $2133.24 \mathrm{q}$ \\
\hline & Mean & $2555.65 \mathrm{a}$ & $2489.00 \mathrm{a}$ & $2617.89 \mathrm{a}$ & $2370.34 \mathrm{a}$ & $(-)$ \\
\hline & $\mathrm{CV}$ & & & 19.45 & & \\
\hline \multirow{4}{*}{2} & Without Al & 7416.80 & 7022.55 & 7212.38 & 7108.82 & $7190.14 \mathrm{p}$ \\
\hline & Al Toxicity & 4240.37 & 3411.23 & 4161.62 & 4569.75 & $4095.74 \mathrm{q}$ \\
\hline & Mean & $5828.58 \mathrm{a}$ & $5216.89 \mathrm{a}$ & $5687.00 \mathrm{a}$ & $5839.28 \mathrm{a}$ & $(-)$ \\
\hline & $\mathrm{CV}$ & & & 17.48 & & \\
\hline
\end{tabular}

Remarks: Means associated with the same letters are not significantly different according to Duncan's multiple range tests $(\mathrm{P}<0.05) ;(-)$ : no interaction among factors tested

Table 3. Oil Palm Height on the first and second observation $(\mathrm{cm})$

\begin{tabular}{|c|c|c|c|c|c|c|}
\hline \multirow{2}{*}{ Obs } & \multirow{2}{*}{ Treatments } & \multicolumn{4}{|c|}{ Si Dosage (g/plant) } & \multirow{2}{*}{ Mean } \\
\hline & & $\mathbf{0}$ & 32 & 64 & 96 & \\
\hline \multirow{4}{*}{1} & Without Al & 93.10 & 86.79 & 88.33 & 85.12 & $88.34 \mathrm{a}$ \\
\hline & Al Toxicity & 86.72 & 75.76 & 77.63 & 85.53 & $81.41 \mathrm{a}$ \\
\hline & Mean & $89.91 \mathrm{a}$ & $81.28 \mathrm{a}$ & $82.98 \mathrm{a}$ & $85.32 \mathrm{a}$ & $(-)$ \\
\hline & $\mathrm{CV}$ & & & 12.68 & & \\
\hline \multirow{4}{*}{2} & Without Al & 123.83 & 106.98 & 109.13 & 112.34 & $113.07 \mathrm{a}$ \\
\hline & Al Toxicity & 102.42 & 98.99 & 89.34 & 87.90 & $94.66 \mathrm{~b}$ \\
\hline & Mean & $113.13 \mathrm{a}$ & $102.99 \mathrm{a}$ & $99.24 \mathrm{a}$ & $100.12 \mathrm{a}$ & $(-)$ \\
\hline & $\mathrm{CV}$ & & & 13.22 & & \\
\hline
\end{tabular}

Remarks: Means associated with the same letters are not significantly different according to Duncan's multiple range tests $(\mathrm{P}<0.05) ;(-)$ : no interaction among factors tested

Moreover, proline also acts as free radical scavenger.

Leaf area is a plant growing indicator of photosynthetic process. Leaf is a light receptor as well as a part plant organ plant for photosynthetic process. Table 2 shows that there is no interaction between $\mathrm{Al}$ toxicity and dosage of Si in variable of leaf area. Oil palm which was induced by Al toxicity had narrower leaves compared to oil palm which was not induced by $\mathrm{Al}$ toxicity. Though, it was not significantly and statistically different, the dosage of $64 \mathrm{~g} /$ plant of Si tended to increase leaf area on the first observation while in the second observation the dosage 96 $\mathrm{g} / \mathrm{plant}$ of Si tended to encourage the leaf to reach maximum area. Leaf development was closely related to the process of cell division and differentiation. The increase of $\mathrm{Al}$ concentration of leaf tissue disrupts cell division by bonding phosphate, so it inhibits leaf expansion (Salisbury and Ross, 1995). Deficiency of phosphate leads to a decline of root respiration and enzymatic disturbance which could regulate polysaccharides in the cell wall and also cause the increasing of the cell wall rigidity which then also can inhibit the essential nutrient absorption in the process of cell division 
Table 4. Number of oil palm leaves on the first and second observation (pieces)

\begin{tabular}{|c|c|c|c|c|c|c|}
\hline \multirow{2}{*}{ Obs } & \multirow{2}{*}{ Treatments } & \multicolumn{4}{|c|}{ Si Dosage (g/plant) } & \multirow{2}{*}{ Mean } \\
\hline & & $\mathbf{0}$ & 32 & 64 & 96 & \\
\hline \multirow{4}{*}{1} & Without Al & 11.67 & 13.57 & 13.46 & 13.33 & $13.27 \mathrm{a}$ \\
\hline & Al Toxicity & 12.69 & 12.54 & 13.13 & 12.83 & $12.54 \mathrm{~b}$ \\
\hline & Mean & $12.18 \mathrm{~b}$ & $13.06 \mathrm{a}$ & $13.29 \mathrm{a}$ & $13.08 \mathrm{a}$ & $(-)$ \\
\hline & $\mathrm{CV}$ & & & 4.05 & & \\
\hline \multirow{4}{*}{2} & Without Al & 14.22 & 14.59 & 14.83 & 15.05 & $14.68 \mathrm{a}$ \\
\hline & Al Toxicity & 12.83 & 13.42 & 13.71 & 13.50 & $13.36 \mathrm{~b}$ \\
\hline & Mean & $13.53 \mathrm{a}$ & $14.01 \mathrm{a}$ & $14.27 \mathrm{a}$ & $14.27 \mathrm{a}$ & $(-)$ \\
\hline & $\mathrm{CV}$ & & & 4.03 & & \\
\hline
\end{tabular}

Remarks: Means associated with the same letters are not significantly different according to Duncan's multiple range tests $(\mathrm{P}<0.05) ;(-)$ : no interaction among factors tested

Table 5. Oil palm dry weight on the first and second observation (g)

\begin{tabular}{|c|c|c|c|c|c|c|}
\hline \multirow{2}{*}{ Obs } & \multirow{2}{*}{ Treatments } & \multicolumn{4}{|c|}{ Si Dosage (g/plant) } & \multirow{2}{*}{ Mean } \\
\hline & & $\mathbf{0}$ & 32 & 64 & 96 & \\
\hline \multirow{4}{*}{1} & Without Al & 72.58 & 42.87 & 60.90 & 43.40 & $54.94 \mathrm{p}$ \\
\hline & Al Toxicity & 45.74 & 45.04 & 54.43 & 50.05 & $48.82 \mathrm{p}$ \\
\hline & Mean & $59.16 \mathrm{a}$ & $43.95 \mathrm{a}$ & $57.67 \mathrm{a}$ & $46.73 \mathrm{a}$ & $(-)$ \\
\hline & $\mathrm{CV}$ & & & 23.78 & & \\
\hline \multirow{4}{*}{2} & Without Al & 131.21 & 146.46 & 144.97 & 140.05 & $140.67 \mathrm{p}$ \\
\hline & Al Toxicity & 81.18 & 68.97 & 85.15 & 88.36 & $80.91 \mathrm{q}$ \\
\hline & Mean & $106.19 \mathrm{a}$ & $107.71 \mathrm{a}$ & $115.06 \mathrm{a}$ & $114.20 \mathrm{a}$ & $(-)$ \\
\hline & $\mathrm{CV}$ & & & 26.16 & & \\
\hline
\end{tabular}

Remarks: Means associated with the same letters are not significantly different according to Duncan's multiple range tests $(\mathrm{P}<0.05) ;(-)$ : no interaction among factors tested

Table 6. Table of Correlation Analysis among Variable Observations

\begin{tabular}{cccccc}
\hline & PROLIN & PH & NL & LA & DW \\
\hline PROLIN & 1 & & & & \\
PH & $-0.501^{*}$ & 1 & & & \\
NL & $-0.510^{*}$ & $0.674^{*}$ & 1 & & \\
LA & $-0.697^{*}$ & $0.830^{*}$ & $0.851^{*}$ & 1 & 1 \\
DW & $-0.580^{*}$ & $0.790^{*}$ & $0.860^{*}$ & $0.943^{*}$ & 1
\end{tabular}

Remarks: PROLIN: Proline; PH: Plant height; NL: Number of leaves; LA: Leaf area; DW: dry weight; $(*)$ : significant

such as $\mathrm{Ca}, \mathrm{Mg}, \mathrm{K}, \mathrm{P}$ and water.

First symptom that appeared caused by Al toxicity was undeveloped root system which was caused by inhabitation of cell elongation. The undeveloped roots decreased the efficiency of nutrient and water uptake, so in the long term it can inhibit the growth and development of oil palm. Table 3 shows that there is no interaction between Al toxicity treatment and $\mathrm{Si}$ application in variable of plant height. On the first observation, Al toxicity did not affect negatively on metabolism so that the plant grew normally. The second observation was conducted after the plant suffered physiological alterations caused by Al toxicity which was the occurrence of chlorosis on the leaves. Under Al toxicity condition, the assimilates used to synthesize chlorophyll were translocated to critical parts to recover the condition of the plants with consequence of stress, resulting inthe distruption of chlorophyll synthesis was chlorosis. Limited chlorophyll disrupted the process of photosynthesis thus assimilates production was decreasing and in the long term could possibly inhibit the plant growth as it would be indicated by variable of plant height. On the first and second observation, application of Si up to $96 \mathrm{~g} /$ plant did not show any positive effect on the growth of oil palm with Al toxicity. 
Table 4 shows that there is no interaction between $\mathrm{Al}$ toxicity treatment and $\mathrm{Si}$ application in variable of number of leaves. The number of leaves on the second observation was lower compared to the first observations as caused by the negative impact of $\mathrm{Al}$ toxicity. The lower number of leaves inhibited the photosynthesis. Si application was able to increase the number of oil palm leaves which was already induced by $\mathrm{Al}$ toxicity on the first observation, however the effect of Si disappeared on the second observation. Matichenkov and Calvert (2002) state that the application of Si able is to increase the efficiency of photosynthesis in plants which is induced by abiotic environmental stress, so that assimilates produced is sufficient to establish the growth and development of plants under stress.

Table 5 shows that there is no interaction between $\mathrm{Al}$ toxicity treatment and $\mathrm{Si}$ application in the variable of dry weight. Dry weight of oil palm which was induced by Al toxicity tended to be lower compared to that of oil palm that grew in a normal environment, although it did not differ significantly. This result was in accordance with the research of sorghum by Galvez and Clark (1991) which state that the higher the concentration of Al absorbed, the lower the shoot dry weight and the lower the root. On the second observation, application of Si tended to increase oil palm dry weight though it did not differ significantly.

Al toxicity increases the rate of proline synthesis in oil palm leaf tissue for twice (Table 1). Table 6 shows that proline content in oil palm leaves was negatively correlated with plant height, number of leaves, leaf area and dry weight. The increase of proline concentration in leaf tissue potentially inhibited the growth of oil palm since amino acids were synthesized into proline compound. An amount of amino which was used for other metabolic activity declined drastically and risked of lowering rate of plant growth though the plant was potentially more tolerant to Al toxicity. Ashraf and Foolad (2007) state that while many studies have indicated a positive relationship between accumulation of proline and plant stress tolerance, some have argued that the increases in its concentrations under stress is a product of and not an adaptive response to stress.

Table 6 provides information that proline compound concentration in tissue was not correlated with oil palm growth. The increase of proline compound concentration in leaf tissue did not inhibit the growth rate of oil palm. Particularly, the growth of oil palm under Al toxicity exposure was determined by other factors including concentration of proline compound.
This condition also proved that the level of proline concentration in oil palm tissue was a product and not a mechanism of toleration of Al toxicity.

\section{CONCLUSION}

Al toxicity increases proline compound content in the tissues of plant and decreases palm's leaf area, plant height, number of leaves, and dry weight. Applying $64 \mathrm{~g} /$ plant of $\mathrm{Si}$ is able to increase the proline content and the dry weight oil palm exposed to Al toxicity. Proline compound content in the plant tissue is not correlated with oil palm growth. This indicates that proline is a product and not a mechanism of tolerance of Al toxicity.

\section{REFERENCES}

Ashraf, M and M.R. Foolad. 2007. Roles of glycine betaine and proline in improving plant abiotic stress resistance. Environmental and Experimental Botany 59: 206-216.

Çelik, Ö. and Ç. Atak. 2012. The effect of salt stress on antioxidative enzymes and proline content of two Turkish tobacco varieties. Turk J. Biol. 36: 339-356.

Clarkson, D.T. 1969. The effect of Aluminium and some other trivalent metal ions on the cell division in the root of Allium cepa. Ann. Bot. $20: 309-315$.

Enggarini, W \& E. Marwani. 2006. Pengaruh cekaman aluminium terhadap kandungan asam organik dalam kalus dan pinak tomat (Lycopersiconesculentum Mill.). Jurnal Agro Biogen. 2 : 24-28.

Galvez, L \& R.B. Clark. 1991. Effects of silicon on growth and mineral composition of sorghum (Sorghum bicolor) grown with toxic levels of aluminium. Dalam Plant-Soil Interactions at Low $\mathrm{pH}$, Proceedings of the Second International Symposium on Plant Soil Interactions at Low pH, Kluwer Academic Publisher, Beckley, WV. June 1990. 815-823.

Hamim, D., Sopandie\& M. Yusuf. 1996. Beberapa karakteristik morfologi dan fisiologi kedelai toleran dan peka terhadap cekaman kekeringan. Hayati. $3: 30$ - 34 .

Hanum, C., W. Q. Mugnisjah, S. Yahya, D. Sopandie, K. Idris \& A. Sahar. 2009. Penapisan kedelai toleran cekaman aluminium dan kekeringan. Forum Pascasarjana. 32 : 295-305.

Huang, P.M., A. Violante. 1997. Pengaruh asam organik terhadapkristalisasi dan sifat permukaan produk pengendapan Al. In : P.M. Huang, M. Schnitzel (Eds). Interaksi Mineral Tanah den- 
gan Organik Alami dan Mikroba. UGM Press. Yogyakarta.

IMA (Indonesian Ministry of Agriculture). 2010. Area and Production by Category of Producers: Palm Oil, Direktorat Jenderal Perkebunan. Kementerian Pertanian. http: // ditjenbun .deptan.go.id/index.php/direktori/3isi/4-kelapa-sawit.html. (Diakses tanggal 26 Agustus 2015).

Jain, M., G. Mathur, S. Koul\& N. B. Sarin. 2001. Ameliorative effects of prolin on salt stressinduced lipid peroxidation in cell lines of groundnut (Arachishypogeae L.). Plant Cell Rep 20 : 463-468.

Matichenkov, V.V \& D.V. Calvert. 2002. Silicon as beneficial element for sugarcane. Journal Society of Sugarcane Technologiest. $22: 21-30$.

Rengel, Z. 1997. Role of calcium in aluminium. New Phytol. 21: 499 - 513.

Risza, S. 2008. Kelapa Sawit dan Upaya Peningkatan Produktivitas. Penerbit Kanisius. Jakarta.
Rorison, J.W. 1973. The effect of acidity on the nutrient uptake and physiology of plants. In Dost. 1 : 223-254.

Salisbury, F.B. \& C.W. Ross. 1995. FisiologiTumbuhan (diterjemahkan oleh Lukman dan Sumaryono). ITB. Bandung.

Savant, N. K, G.H. Korndorfer, L.E. Datnoff \& G.H. Snyder. 1999. Silicon nutrition and sugarcane production : a review. Journal Plant and $\mathrm{Nu}-$ trition. 22 : 1853-1903.

Shahnaz, G., E. Shekoofeh, D. Kourosh \& B. Moohamad bagher. Interactive effects of silicon and aluminum on the malondialdehyde (MDA), proline, protein and phenolic compounds in Borago officinalis L. Journal of Medicinal Plants Research. 5 : 5818-5827.

Umebese, C.U., T.O. Olatimelitin \& T.A. Ogunsusi. 2009. Salicylic acid protects NR activity, growth and proline in amaranth and tomato plants during water deficit. American Journal of Agr. \& Biological Sciences. 4 : 224-229. 